\title{
DEPOSITION OF CALCIUM CARBONATE IN KARST CAVES: ROLE OF BACTERIA IN STIFFE'S CAVE
}

\author{
Claudia ERCOLE*, Paola CACCHIO*, Giorgio CAPPUCCIO**, \\ Aldo LEPIDI*
}

\begin{abstract}
Bacteria make a significant contribution to the accumulation of carbonate in several natural habitats where large amounts of carbonates are deposited. However, the role played by microbial communities in speleothem formation (stalactites, stalagmites etc.) in caves is still unclear. In bacteria carbonate is formed by autotrophic pathways, which deplete $\mathrm{CO}_{2}$ from the environment, and by heterotrophic pathways, leading to active or passive precipitation. We isolated cultivable heterotrophic microbial strains, able to induce $\mathrm{CaCO}_{3}$ precipitation in vitro, from samples taken from speleothems in the galleries of Stiffe's cave, L'Aquila, Italy. We found a large number of bacteria in the calcite formations $\left(1 \times 10^{4}\right.$ to $5 \times 10^{9}$ cells $\left.\mathrm{g}^{-1}\right)$. Microscopic examination, in laboratory conditions at different temperatures, showed that most of the isolates were able to form calcium carbonate microcrystals. The most crystalline precipitates were observed at $32^{\circ} \mathrm{C}$. No precipitation was detected in un-inoculated controls media or in media that had been inoculated with autoclaved bacterial cells. X-ray diffraction (XRD) analysis showed that most of the carbonate crystals produced were calcite. Bacillus strains were the most common calcifying isolates collected from Stiffe's Cave. Analysis of carbonate-solubilization capability revealed that the non-calcifying bacteria were carbonate solubilizers.
\end{abstract}

Keywords: bacteria, calcium carbonate precipitation, karst cave.

\section{Introduction}

Geomicrobiology examines the role of micro-organisms in a wide range of geological processes, such as rock dissolution, rock formation, the transformation of soils and sediments, genesis, and the degradation of minerals and fossil-fuels (Ben Omar et al., 1997; Ehrlich, 1990).

This discipline is closely related to other scientific disciplines, such as microbial-

*Department of Basic and Applied Biology, University of L'Aquila, Coppito, L'Aquila Italy, e-mail: claudia.ercole@aquila.infn.it

**Istituto per lo Studio dei Materiali Nanostrutturati (CNR-ISMN) Via Salaria Km29300, CP. 10, Area della Ricerca di Roma 00016. Monterotondo Sc. Roma. Italy 
ecology and biogeochemistry (Ben Omar et al., 1997).

The microorganisms in the biosphere, including in caves can aid the concentration, dispersion, and fractionation of matter.

For example, microorganisms can promote the dissolution of poorly soluble minerals, such as $\mathrm{CaCO}_{3}$, iron and manganese hydroxides, to soluble compounds. They can also act upon mixtures of inorganic compounds, selectively concentrating or diluting them. Finally, microorganism can accumulate inorganic materials via processes such as intracellular deposition, adsorption and cellular fixation, and extracellular precipitation of insoluble compounds (Ben Omar et al., 1997). The field of biomineralization is devoted to the study of microbes that can act as concentrating agents (Lowenstan \& Weiner, 1989).

\section{Biomineralization}

Biomineralization is the process by which organisms form minerals, by creating the physical and chemical conditions necessary for mineral formation and growth.

Some aspects of biomineralization overlap with some aspects of geomicrobiology and of other scientific disciplines.

Organisms that can precipitate minerals are present in all taxonomic groups, from Bacteria to Chordata, even though the processes involved can be very different.

The most abundant cation in most known biominerals is calcium and the most abundant anions are carbonates.

Microbial communities also play an important role in the formation of some minerals deposits. Microbial metabolism is highly versatile and is characterised by the frequent release of metabolic products, such as organic acids, sugars and enzymes. These products can change the physico-chemical environment, (e.g. pH), they can also catalyse redox reactions, which directly or indirectly change the redox state of metals, favouring deposition and dissolution. For example, the most abundant Mnand Fe-containing minerals are Mn-dioxides and ferric oxides, respectively. These minerals are formed by the oxidation of $\mathrm{Mn}$ or divalent-Fe in the presence of free $\mathrm{O}_{2}$ or highly oxidised compounds - such as nitrates and sulphates - by chemolithotrophic microorganisms.

The type of mineral produced, however, is more dependent on the environmental conditions in which the micro-organism is living than on the biological processes involved in its formation. Thus, the same bacterial species can produce different minerals in different environmental conditions.

A relationship exists between the microbial activities of the $S$ cycle and elementary $S$ deposits in both marine and terrestrial environments (Northup \& Lavoie, 2001)

One of the most relevant and well-known examples of mineralization driven by bac- 
teria is the precipitation of $\mathrm{CaCO}_{3}$ (Rivadeneyra et al., 1993).

\section{Biotic and abiotic precipitation of $\mathrm{CaCO}_{3}$}

In natural conditions, the precipitation of $\mathrm{CaCO}_{3}$ can be considered to be the result of a series of chemical and biochemical processes. $\mathrm{CaCO}_{3}$ can exist in three different polymorphic forms: calcite, aragonite and vaterite. Calcite is the most stable form - and is thus the most common form of carbonate on the Earth's surface, where it is the most common constituent of sedimentary rocks.

Equilibrium exists between insoluble (carbonate) and soluble (bicarbonate) forms in water:

$$
\mathrm{CaCO}_{3}+\mathrm{CO}_{2}+\mathrm{H}_{2} \mathrm{O} \Leftrightarrow=\mathrm{Ca}\left(\mathrm{HCO}_{3}\right)_{2}
$$

The depletion of $\mathrm{CO}_{2}$ from water favours the deposition of carbonate.

Abiotic chemical precipitation can occur due to a decrease in the partial $\mathrm{CO}_{2}$ pressure, the shaking or stirring of the water, an increase in temperature, or a decrease in hydrostatic pressure.

However, the contribution of biological systems to limestone precipitation (biotic precipitation) is due to:

- the production of internal and external skeletons by eukaryotes (shells, skeletons).

- the production of carbonate by autotrophic and etherotrophic bacteria and by fungi (Le Metayer-Levrel et al., 1999).

\section{Role of bacteria in the precipitation of carbonate minerals}

$\mathrm{CaCO}_{3}$ precipitation is one of the most relevant examples of bacterial mineralization and can be traced back to the Precambrian period.

Both autotrophic and heterotrophic bacteria, including sulphur, photosynthetic-, and nitrogen-fixing bacteria, which hydrolyse urea and cellulose, are involved in $\mathrm{CaCO}_{3}$ precipitation. Boquet et al. (1973) stated that, - in favourable conditions, - most of these bacteria could produce calcite crystals. The mechanisms, by which bacteria precipitate carbonate, however, are still unclear. Metayer-Levrel et al. (1999) and Castanier et al. (2000) showed that the precipitation of $\mathrm{CaCO}_{3}$ by micro-organisms can occur via several different pathways.

In autotrophic bacteria three major pathways are involved: methanogenesis and oxygenic and anoxygenic photosynthesis. All three pathways involve the use of $\mathrm{CO}_{2}$. In heterotrophic bacteria, several pathways from the nitrogen and sulphur cycles are involved in the precipitation of carbonate. For example the ammonia produced during the nitrogen cycle leads to an increase in $\mathrm{pH}$, which then shifts the carbonatebicarbonate equilibrium towards carbonate production. 
Micro-organisms can also act as crystallisation nuclei for the formation of $\mathrm{CaCO}_{3}$ crystals. Rivadeneyra et al. (1996) demonstrated that $\mathrm{Ca}$ ions bind to microbial cell surfaces (possibly to capsular structures). When these surfaces become saturated with $\mathrm{Ca}$ ions, the ions start to aggregate, thus initiating the first crystallisation nucleus. Crystals then grow from these structures.

\section{A CASE STUDY: STIFFE'S CAVE}

\section{Isolation of calcifying bacteria from speleothems}

The following types of sample were collected from speleothems in Stiffe's Cave, a limestone cave located near L'Aquila (central Italy) that is open to the general public:

- Soda straw stalactites from an area located close to a pathway that is used by visitors (sample A)

- Stratified tubular stalactites from an area located far from a pathway that is used by visitors (sample B)

- Stratified tubular stalactites from an area located far from a pathway that is used by visitors (sample C)

- Flowstones (sample D)

Speleothems samples were collected in sterile conditions and kept in sterile tubes at $4^{\circ} \mathrm{C}$ until analyses. For the microbiological analyses, $1 \mathrm{~g}$ of the sample was crushed by use of mortar and pestle and then suspended in $9 \mathrm{~mL}$ of sterile saline solution ( $1 \times 10^{-1}$ dilution). Ten-fold serial dilution was made until to $1 \times 10^{-9}$ dilutions. B-4M (Boquet el al., 1973) plates were inoculated with the diluted samples in triplicate and incubated at $32^{\circ} \mathrm{C}$ for two weeks. Individual colonies were selected and purified by repeated subculture on solid B-4M.

\section{Precipitation of calcium carbonate by micro-organisms}

We tested the ability of selected microbial strains to precipitate calcium carbonate on both liquid and solid B-4M.

$\mathrm{B}-4 \mathrm{M}$ plates were inoculated with strains that were able to precipitate calcium carbonate and incubated at 4,22 and $32^{\circ} \mathrm{C}$ in aerobic conditions. All experiments were carried out in triplicate. The controls consisted of uninoculated medium and medium inoculated with bacterial cells that had been autoclaved at $120^{\circ} \mathrm{C}$ for 20 min. Plates were routinely examined under a light microscope every day for 25 days (Leitz Biomed) for the presence of crystals.

The morphology and size of the crystals and micro-organisms were analysed by scanning electron microscopy (SEM- Philips XL30CP). 
The mineral composition of the precipitates was characterised by power X-ray diffraction (XRD). Crystalline phases were identified by use of the ICDD database (JCPDS). Two purification procedures were used, depending on concentration of crystals.

Cultured solid medium was dried at 22 or $32^{\circ} \mathrm{C}$. The agar medium was cut into $10 \times 30 \times 0.5 \mathrm{~mm}$ blocks, and those richest in crystallites were fixed into adhesive tape. This tape was placed in the middle of a diffractometer in a " $U$ " shaped sample holder to minimise background signals. Samples with a low crystallite content were collected as described by Rivadeneyra et al. (1994). Washed crystals were air-dried at $37^{\circ} \mathrm{C}$ and held by a glass sampler for X-ray measurements.

\section{Cyto-morphological and biochemical characterisation}

Calcifying bacterial strains were identified by phenotypic tests. We used a light microscope to examine the size and morphology of the cells. The cells were stained according to the Shaeffer-Fulton method and the presence of endospores in the cells was observed by phase-contrast microscopy or by light microscopy. Bacterial cells were Gram stained (bioMérieux, Marcy-l'Etoile/France).

The morphological changes that occur during the growth cycle were monitored for some bacterial strains grown on specific media (Jones \& Keddie, 1992). Conventional tests (Bergey's Manual, 1986) and the API $50 \mathrm{CH}$ and $20 \mathrm{E}$ test kits (bioMérieux) were used to characterise the biochemical nature of the cells. The nitrate- and sulphate-reducing capacity of the cells (Cappuccino \& Sherman, 1987) and their ability to oxidise ammonia to nitrite (Pochon \& Tardieux, 1962) were also assayed.

\section{Results and discussion}

This preliminary study involved the isolation and characterisation of all cultivable micro-organisms and of calcifying bacteria from a carbonate concretion in Stiffe's cave. The amount of bacteria isolated varied enormously between the different samples (Table 1). Bacteria might have been scarce in some areas due to their presence having a trivial origin or due to other reasons (e.g. percolation, contamination due to the presence of Chiroptera, other cave-dwelling animals and visitors). The existence of millions or billions of cells per gram, such as in samples C and D, require suitable local conditions for growth. The samples that contained the most bacteria also tended to contain a higher proportion of calcifying strains. Furthermore, these samples contained fewer different microbial species. All of these findings confirm the permanent nature of these bacterial communities. 
Table 1 - Density of bacteria in the speleothem samples: Soda straw stalactite situated near to a pathway used by tourists (sample A), Stratified tubular stalactites located some distance away from a pathway used by tourists (samples B and C), Mamelons (sampleD).

\begin{tabular}{|l|c|c|c|}
\hline SPELEOTHEMS & $\begin{array}{c}\text { WALL } \\
\text { THICKNESS } \\
(\mathbf{m m})\end{array}$ & $\begin{array}{c}\text { MICROBIAL } \\
\text { DENSITY (CFU/g) }\end{array}$ & $\begin{array}{c}\text { CALCIFYING } \\
\text { STRAINS (\%) }\end{array}$ \\
\hline Sample A & 0.5 & $4 \times 10^{3}$ & 11 \\
\hline Sample B & $0.3-0.6$ & $4 \times 10^{5}$ & 54 \\
\hline Sample C & $0.4-1.1$ & $4 \times 10^{6}$ & 63 \\
\hline Sample D & & $5 \times 10^{9}$ & 91 \\
\hline
\end{tabular}

We then concentrated on the non-mycelia bacteria, particularly the 22 calcifying strains isolated from flowstones. We evaluated the ability of these strains to produce carbonate precipitates in vitro at three different temperatures $\left(4^{\circ} \mathrm{C}, 22^{\circ} \mathrm{C}\right.$ and $\left.32^{\circ} \mathrm{C}\right)$. We also analysed, the cyto-morphological and biochemical characteristics of these strains.

The precipitation kinetics showed that the calcifying bacteria needed 7 days to precipitate carbonates at $32^{\circ} \mathrm{C}, 15$ days at $22^{\circ} \mathrm{C}$, and 25 days at $4{ }^{\circ} \mathrm{C}$ (Fig. 1). Thus high

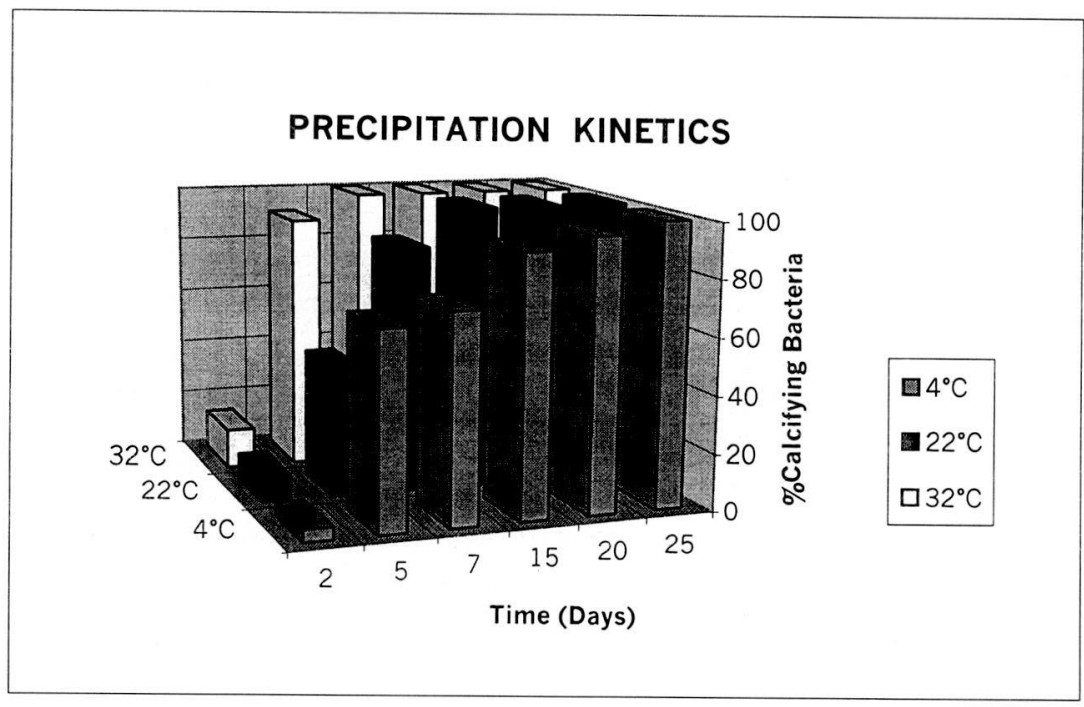

Fig 1 - Precipitation of calcium carbonate by bacterial strains. 
temperatures decrease the time necessary for the initiation of the precipitation process, which in turn increases the precipitation rate. No precipitation was observed on any of the control plates. X-ray diffraction measurements showed that the bacteria mainly precipitate calcite and sometimes precipitate a mixture of calcite and vaterite. XRD analysis also showed that the carbonate formations from which the micro-organisms were isolated are formed from pure calcite (Fig. 2). We checked the

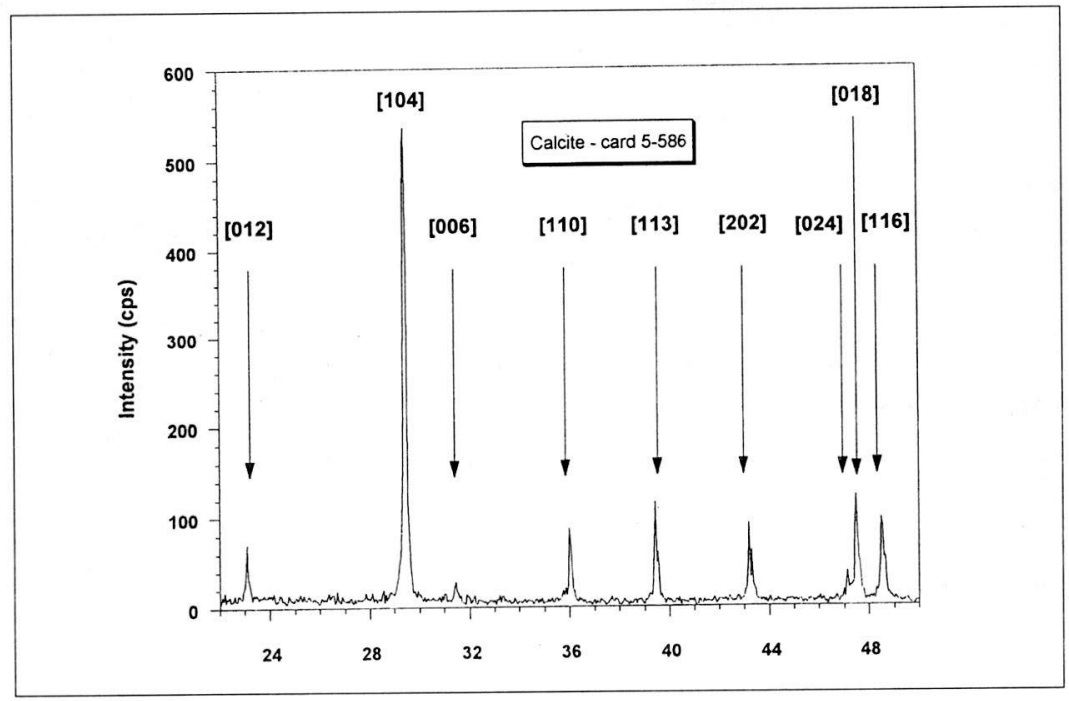

Fig. 2 - XRD spectrum of a stalactite sample.

calcifying ability of the isolated bacteria on a solid and in a liquid culture. Figures 3 , 4, 5 and 6 show calcite crystals adhered to the glass surface and precipitated from Bacillus sphaericus (Fig.3) and Bacillus firmus (Figs 4,5,6) after 5 months at $32^{\circ} \mathrm{C}$. The morphology and sizes of the calcite crystals were correlated with the species involved in the calcification process. Bacterial prints are clearly visible on the surface of the crystal in Fig. 4.

Biochemical characterisation of the calcifying bacteria showed that many strains were able to reduce nitrates and sulphates, and that some strains were also able to oxidise ammonium ions. The isolated bacteria were all able to ferment and /or to oxidise several sugars and their by-products.

Such metabolic behaviours could be related with the depuration of water percolating in hypogean cavities. Furthermore, the redox processes primed by micro-organism present in the percolation water may modify the amount of dissolved $\mathrm{CO} 2$, which would modify the chemical-physical conditions and induce carbonate precipitation. 


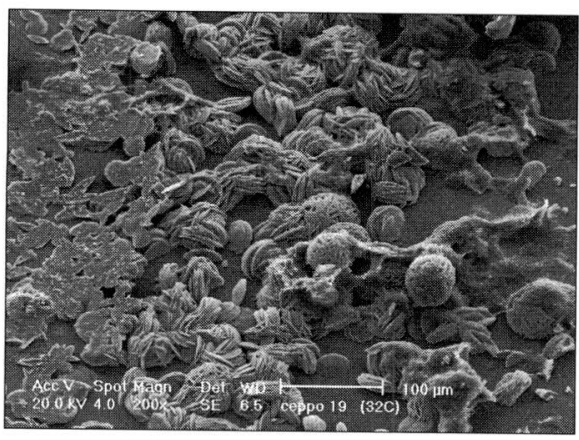

Fig. 3

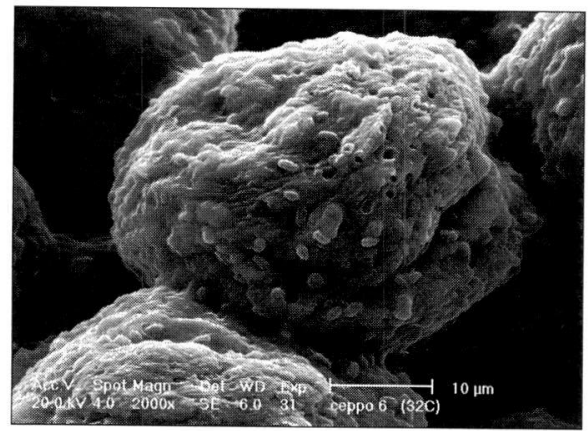

Fig. 5

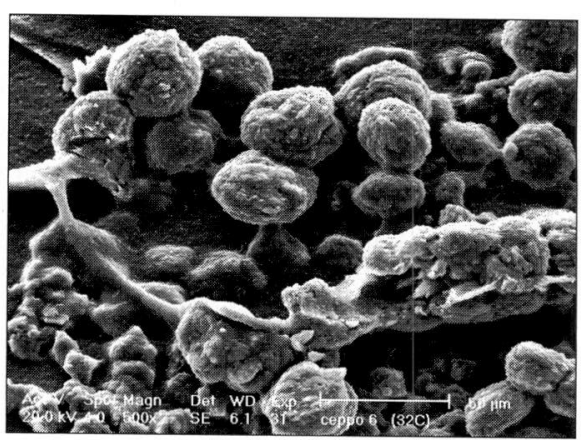

Fig. 4

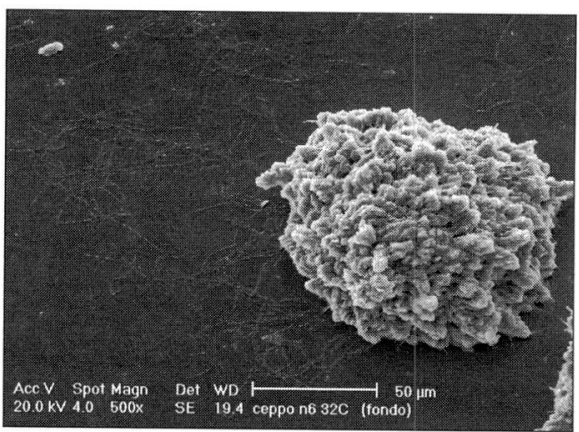

Fig. 6

Fig. 3, 4, 5, 6 SEM of calcite crystals precipitated from Bacillus sphaericus (Fig.3) and from Bacillus firmus (Figs. 4, 5, 6). The imprints of the bacteria are clearly visible on the crystal surface in Fig. 5. In Fig. 6 microbial cells can be seen around and near to the crystals.

Thus, bacteria are "indirectly" involved in the precipitation of carbonate inside caves. However, it is not clear whether they have a "direct" role in the formation of calcium carbonate.

We identified the calcifying bacteria according to their cyto-morphological characteristics and biochemical profiles as described by Bergey (1986). The micro-organisms isolated from the formations were quite homogeneous: $77 \%$ of the calcifying bacteria belonged to the Bacillus genus, which consists of heterotrophic spore-forming bacteria able to survive in adverse environmental conditions. The remainder strains belonged to the Arthrobacter genus (Fig. 7). Members of the Arthrobacter genus, most of which are epigean, aerobic, chemoeterotrophic bacterial, have an important role in the mineralization of organic matter. The genus Arthrobacter is extremely common in soil and in both epigean and hypogean sediments (Gounot, 1967). They are able to survive in such harsh environments because of their capaci- 


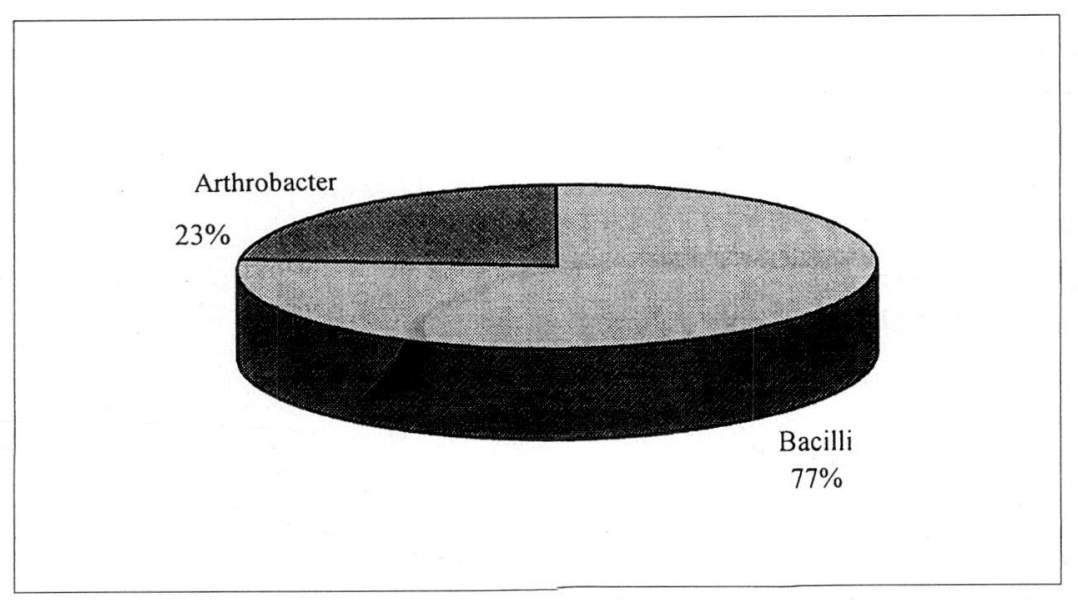

Fig. 7 - Incidence of bacilli and arthrobacters among the calcifying bacteria isolated from Stiffe's Cave.

ty to utilise a wide range of nutrients and their ability to adapt to low temperatures (Cacciari \& Lippi, 1986). This may be correlated with the ability of many Arthrobacter to secrete a biopolymer, in which they often become trapped. This biopolymer acts as a water and nutrient reserve by limiting exchanges with the external environment. (Hobbie \& Fletcher, 1988).

\section{Concluding remarks}

We found a large number of calcifying bacteria associated with speleothems from Stiffe's Cave. However, it is difficult, on the basis of the results obtained, to define clearly the role played by bacterial communities in the formation of carbonate formations. The analysis of microbial communities from different karst caves and different speleothems from a single cave may help us to elucidate this crucial point. In conclusion, our results show that:

- Most of the isolates from Stiffe's Cave induced $\mathrm{CaCO}_{3}$ precipitation in vitro (no crystals were found in the controls). The temperature effect suggested that these bacteria are actively involved in the precipitation process. The precipitated crystals were mostly calcite.

Most of the calcifying bacteria belong to the Bacillus and Arthrobacter genera. The nutritional and ecological characteristics of these genera are typical of bacteria from waters percolating through the soil surface and deeper layers.

Calcite deposition does not seem to be restricted to a small numbers of bacteria in complex microbial populations. Most of the bacteria found in caves induce calcite precipitation, showing that there is a correlation between carbonate deposition and 
microbial global balances.

- XRD analyses did not reveal elements such as Fe, Mn in speleothems samples or in the precipitates obtained in laboratory conditions. We still do not know if any relationships exist between the redox metabolisms of these elements and carbonate deposition.

It will be useful to verify whether calcifying bacteria dissolve these elements, thus justifying their absence from the biogenic sediments.

\section{Acknowledgements}

The authors would like to thank Prof. M. Del Gallo for helpful discussions and for revising the manuscript. We are grateful to M. Panzanaro for providing the cave samples.

\section{References}

BEN OMAR N., ARIAS J.M., GONZALEZ-MUÑOZ M.T., 1997 - Extracellular bacterial mineralization within the context of geomicrobiology. Microbiologia SEM.:161-172.

BUTLER J.P. (Eds), 1986 - Bergey's Manual of Systematic Bacteriology. Vol. 2 Lippincott Williams \& Wilkins. Baltimore-Maryland USA.

BOQUET E., BORONAT A., RAMOS-CORMENZANA A., 1973 - Production of calcite (calcium carbonate) crystals by soil bacteria is a general phenomenon. Nature, 246: 527-529.

CACCIARI I. \& LIPPI D., 1986 - Arthrobacters: successful arid soil bacteria. A review. Arid Soil Res. Rehabil. 1:1-30.

CAPPUCCINO J.G. \& SHERMAN N., 1987 - Microbiology a laboratory manual. The Benjamin/Cummings Publishing Company, Inc., Redwood City.

CASTANIER S., LE METAYER-LEVREL G., PERTHUISOT J-P, 2000 - Bacterial roles in the precipitation of carbonate minerals. In: Ridding R.E. \& Awramik S.M. (Eds.) - Microbial Sediments, Springer-Verlang, Berlin Heidelberg: 32-39.

EHRLICH H. L., 1990 - Geomicrobiology, Marcel Dekker, New York.

GOUNOT A.M, 1967 - La microflore des limons argileux souterrains: son activité productrice dans la biocoenose cavernicole. Ann. Spél. 22:23-143.

HOBBIE J.E. \& FLETCHER M.M., 1988 - The aquatic environment in Microorganisms in action: concepts and applications in microbial ecology.(Ed.) J.M.Lynch and Hobbie J.E.

LE METAYER-LEVREL G., CASTANIER S., ORIAL G., LOUBIÈRE J.F., PERTHUISOT 
J-P, 1999 - Applications of bacterial carbonatogenesis to the protection and regeneration of limestones in buildings and historic patrimony. Sedimentaty Geology, 126: 25-34.

LOWENSTAN H.A. \& WEINER S., 1989 - On biomineralization. Oxford University Press, New York.

NORTHUP D.E. \& LAVOIE K.H., 2001- Geomicrobiology of caves: a review. Geomicrobiology Journal, 18 :199-222.

POCHON J. \& TARDIEUX P., 1962 - Techniques d'Analyse en Microbiologie du Sol. La Tourelle, St. Mandè, France.

RIVADENEYRA M.A., DELGADO G., DELGADO R. DEL MORAL A., FERRER M.R., RAMOS-CORMENZANA A., 1993 - Precipitation of carbonates by Bacillus sp. isolated from saline soils. Geomicrobiology Journal, 11: 175184.

RIVADENEYRA M.A., DELGADO R., DEL MORAL A., FERRER M.R., RAMOS-CORMENZANA A., 1994 - Precipitation of calcium carbonate by Vibrio spp. from an inland saltern. FEMS Microbiol. Ecol. 13: 197-204.

RIVADENEYRA M.A., RAMOS-CORMENZANA A., DELGADO G., DELGADO R., 1996 - Process of carbonate precipitation by Deleya halophila. Current Microbiology, 32: 308-313. 